\title{
Evaluation of Lonicera etrusca var. etrusca Santi (Caprifoliaceae) Stem and Leaf in Terms of Anatomical Structures and Some Phenolic Compounds
}

\author{
(1) Derya ÇIÇEK POLAT, (1) Muhammed Mesud HÜRKUL* \\ Ankara University, Faculty of Pharmacy, Department of Pharmaceutical Botany, Ankara, Türkiye
}

\begin{abstract}
Objectives: The genus Lonicera includes medicinally important plants. Two varieties of L. etrusca have been recorded in Türkiye. Anatomical structures and phytochemical contents are important in the diagnosis and identification of medicinal plants. This study included stem and leaf anatomy of L. etrusca var. etrusca and high performance liquid chromatography (HPLC) analysis of the methanol extracts obtained from these parts. Materials and Methods: Plant materials were collected from Ankara. Methanol extracts were prepared from the stems and leaves by ultrasonic bath. The amounts of chlorogenic acid and caffeic acid that are major compounds in the stem and leaves, were determined by HPLC. For anatomical studies, specimens were preserved in $70 \%$ alcohol. Transverse and surface sections were prepared by hand. Detection of tissues was performed using Sartur reagent. Anatomical specimens were examined using a light microscope and microphotographed.

Results: In HPLC analysis, the highest amount of chlorogenic acid was determined in the leaf (1.148\%), and the highest amount of caffeic acid $(0.156 \%)$ was determined in the stem. In the anatomical analysis, it was observed that the stem was disc-shaped and hollow; pericycle is in a ring form, consists of fibre-like cells with thick walls and wide lumina; cork occurs adjoining pericyclic fibers; thin-walled pith cells containing dense druse crystals. The leaf lamina is bifacial in the transverse section; palisade and spongy parenchyma, both contain abundant starch grains; solitary druse crystals are sparse in the leaf mesophyll; the stomata were observed only on the lower surface with 3-5 subsidiary cells. With this study, $L$. etrusca var. etrusca has been clarified in terms of its anatomical structures and phenolic compounds.

Conclusion: The chemical contents and anatomical structures of the plant may contain important information that can be used in classification. This study may support in taxonomically classification for the L. etrusca var. etrusca.
\end{abstract}

Key words: Lonicera etrusca var. etrusca, Caprifoliaceae, HPLC, plant anatomy, Türkiye

\section{INTRODUCTION}

Caprifoliaceae family includes herbs and small trees, its native range is mainly north temperate and the medically important genera of the family are Viburnum L., Lonicera L., and Sambucus L.1,2

The genus Lonicera spreads from temperate and subtropical Northern Hemisphere to Malaysia and includes 200 accepted species and six species of Lonicera are naturally grown in Türkiye.1-3 L. etrusca Santi grows naturally in Türkiye and is known for its yellowish corolla, red berries, obovate-oval leaves, and hollow young branches. Two varieties of L. etrusca are in Türkiye, L. etrusca var. etrusca Santi and L. etrusca var. hispidula Boiss., where L. etrusca var. etrusca is with the widest distribution in the genus Lonicera is grown in Türkiye. L. etrusca var. etrusca has young shoots, upper leaves, flowers glabrous, 
and lower leaves sparsely hairy to glabrous features, while $L$. etrusca var. hispidula are young shoots, upper leaves, flowers densely glandular-pubescent and lower leaves pubescent, eglandular. ${ }^{3}$ Determination and identification are important for the plants as they are used in traditional medicine. The chemical contents and anatomical structures of the plant may contain important information that can be used in classification. Previous studies have been generally conducted on L. etrusca, regardless of varieties.

Lonicera is one of the most important genera in family, especially for its use in traditional Chinese medicine (TCM). L. japonica Thumb. is used for the treatment of febrile illnesses, sores, and swellings in $\mathrm{TCM}^{4-7} \mathrm{~L}$. caerulea $\mathrm{L}$. has therapeutic uses for hypertension, bacterial infections, and gastrointestinal disorders in northern Russia, China, and Japan. ${ }^{8}$ L. quinquelocularis Hard. is used for its anti-inflammatory effect. ${ }^{9}$ In Türkiye, L. etrusca var. etrusca is used for its diuretic effect, ${ }^{10}$ while $L$. caprifolium L. is used as a laxative and emetic."

The family contains valerianic acid, aucubin glycosides, saponins, coumarins, and cyanogenetic glycosides. ${ }^{2}$ In phytochemical studies with Lonicera species, iridoids, bis-iridoids, triterpene saponins, phenolic acids, flavonoids, coumarins, anthocyanins, and monoterpene alkaloids were determined.12-15 Fruits of Lonicera species (L. altaica Pall., L. caerulea L., and L. edulis Turcz. Ex Freyn) have major phenolic compounds such as flavonoids (e.g. rutin, quercetin, isoquercetin), anthocyanins (e.g. cyanidin, peonidin, delphidin glucosides), phenolic acids (e.g. gallic, vanilic, caffeic, ferrulic, chlorogenic, and genistic acids).$^{16}$ Phenolic compounds in plants have important biological and pharmacological effects. Studies have shown that these compounds have significant antioxidant, antimicrobial, antiinflammatory, and anticancer effects. ${ }^{17,18}$

In this study, the leaf and stem anatomy of L. etrusca var. etrusca, which is widely distributed in Türkiye, was examined in detail and its characteristic structures were revealed. It was also evaluated in terms of phenolic compounds with significant biological activity. This is the first report on this species, in which both anatomical features are evaluated and phenolic compound quantification is performed.

\section{MATERIALS AND METHODS}

\section{Plant material}

The plant material was collected from Beynam Forest (Ankara, Türkiye) in 2020 (Figure 1). A voucher specimen was deposited in the Herbarium (AEF 30738) of Faculty of Pharmacy, Ankara University (Türkiye).

\section{High performance liquid chromatography (HPLC) analysis}

For HPLC analysis, methanol extracts of the air-dried stem and leaves were prepared. Powdered samples were extracted with methanol (Merck) using an ultrasonic bath. After the extracts were filtered and then concentrated with an evaporator. ${ }^{19} \mathrm{HPLC}$ analysis was performed on Agilent 1100 series with diode array

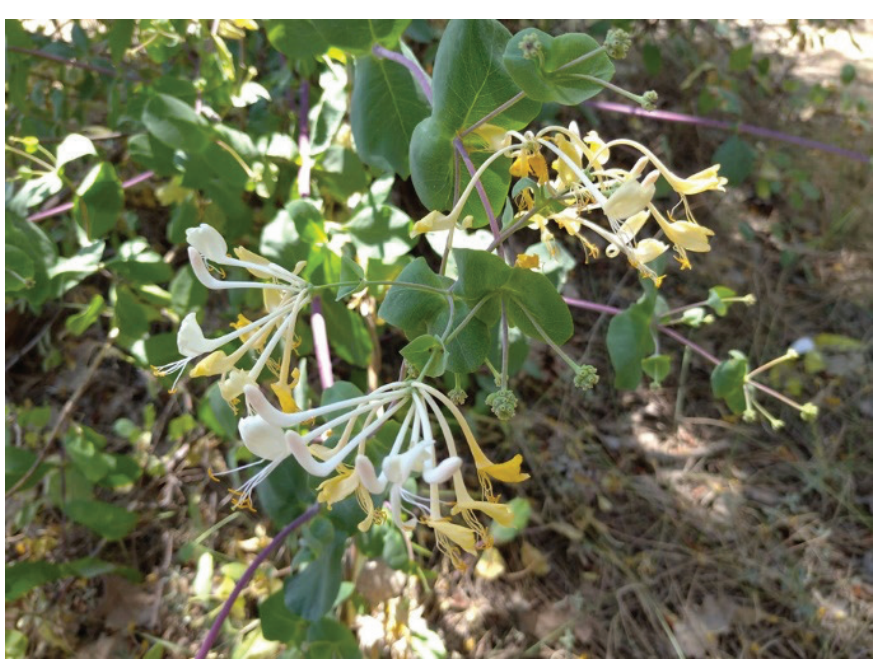

Figure 1. Lonicera etrusca var. etrusca

detector using a Waters Spherisorb C18 column $(25 \mathrm{~cm} \times 4.6$ $\mathrm{mm}, 5 \mu \mathrm{m}$ ) maintained at $40^{\circ} \mathrm{C}$. In a gradient, $0.01 \%$ formic acid (Sigma-Aldrich) (A) and acetonitrile (Sigma-Aldrich) (B) were used as the mobile phase, with a flow rate of $1 \mathrm{~mL} / \mathrm{min}$. The detection wavelength was $300 \mathrm{~nm}$ and the injection volume was $20 \mu \mathrm{L} .^{20}$ After analysis, method validation was performed. Sample extracts $(4 \mathrm{mg} / \mathrm{mL})$ and stock standard solutions of each compound $(500 \mu \mathrm{g} / \mathrm{mL}$ ) were prepared by dissolving in methanol. For the calibration curve, chlorogenic acid (Sigma, Aldrich) and caffeic acid (Sigma, Aldrich) standards were investigated by injecting different concentrations, in triplicate. The precision of the method was determined by carrying on intra-day and inter-day variations and these variations were expressed by the relative standard deviation (RSD). Limit of detection (LOD) and limit of quantification (LOQ) were established at a signal/noise of 3 and 10 , respectively. For LOD and LOQ, 10 injections of chlorogenic and caffeic acids were prepared and averaged. For recovery assay, it was carried out by spiking 3 different known concentrations of standards into the sample solution. These mixtures were analyzed by the same method used. Robustness of the method was evaluated by changing the mobile phase composition, column temperature, flow rate, and detector wavelength.

\section{Light microscope analysis}

The samples for anatomical studies were preserved in $70 \%$ alcohol. The transverse and surface sections were cut by hand with a razor blade in microscopic preparation form. Sartur solution was used in microscopic examinations. ${ }^{21}$ The anatomical analysis and the microphotographs were taken using a Leica DM 4000B.

\section{Statistical analysis}

All analyses were conducted out at least in triplicate and the mean values were calculated. The mean, SD, and RSD data mentioned in the article, linear regression analysis and calculations were made using the Microsoft Excel 2016 program. 


\section{RESULTS}

\section{HPLC analysis}

In this study, stem and leaves of L. etrusca var. etrusca were analyzed quantitatively for their chlorogenic and caffeic acid content using HPLC.

Yields of stem and leaf extracts were $8.59 \%$ and $13.69 \%$, respectively. The chlorogenic and caffeic acid contents of the stem and leaves of $L$. etrusca var. etrusca extracts are shown in Table 1 and their HPLC chromatograms are given in Figures 2 and 3 .

Table 1. Contents of chlorogenic acid and caffeic acid in stem and leaf methanol extracts ( $n: 3)$

\begin{tabular}{lll} 
& Chlorogenic acid $\left(\% \pm \mathrm{SD}^{*}\right)$ & Caffeic acid $\left(\% \pm \mathrm{SD}^{*}\right)$ \\
\hline Stem & $1.043 \pm 0.009$ & $0.156 \pm 0.0009$ \\
\hline Leaf & $1.148 \pm 0.003$ & $0.073 \pm 0.001$ \\
\hline
\end{tabular}

*SD: Standard deviation
For calibration table, the ranges of 5 to $100 \mu \mathrm{g} / \mathrm{mL}$ the calibration plots for chlorogenic and caffeic acids were linear. The LOD values for chlorogenic and caffeic acids were determined as $0.093 \mu \mathrm{g} / \mathrm{mL}$ and $0.068 \mu \mathrm{g} / \mathrm{mL}$; the $\mathrm{LOQ}$ values were determined $0.311 \mu \mathrm{g} / \mathrm{mL}$ and $0.229 \mu \mathrm{g} / \mathrm{mL}$, respectively (Table 2).

Intra-day and inter-day variations were used to determine the precision. The results revealed that RSD values were always less than $2 \%$ (Table 3 ).

For a recovery assay, 3 different known concentrations of chlorogenic and caffeic acids were spiked into the sample solution. The mean extraction recoveries of chlorogenic and caffeic acids were in the range of $97.638 \%-99.795 \%$ and 97.260 $102.092 \%$, respectively (Table 4 ).

It was determined that some changes (mobile phase composition, column temperature, flow rate, and detector wavelength) made for the robustness of the test method did not have a significant effect on chromatographic resolution.

\section{Stem anatomy}

The transverse section of the stem is broadly grooved and hollow disc-like. The single-layer epidermis consists of square-

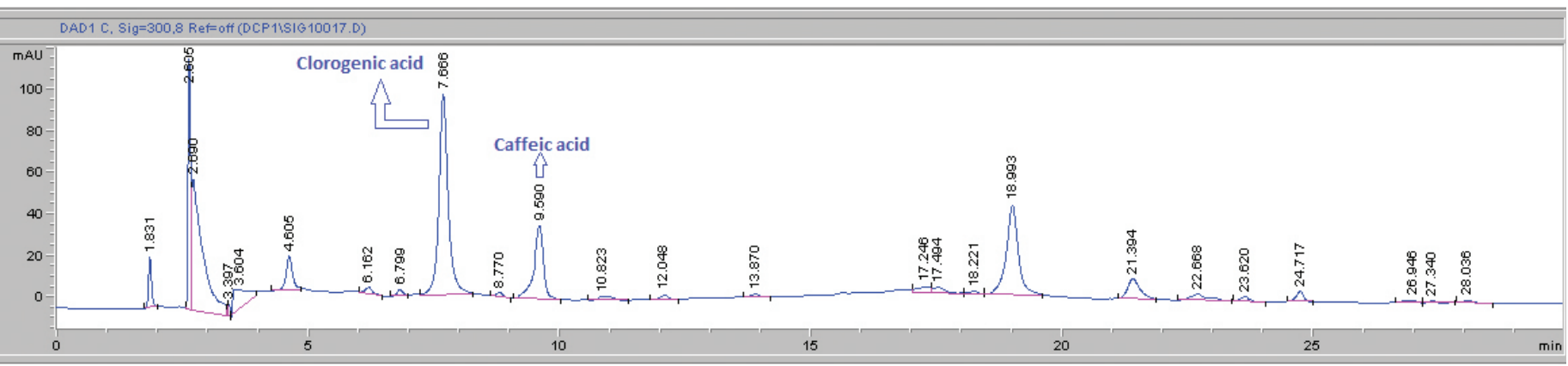

Figure 2. HPLC chromatograms of stem extract of L. etrusca var. etrusca

HPLC: High performance liquid chromatography

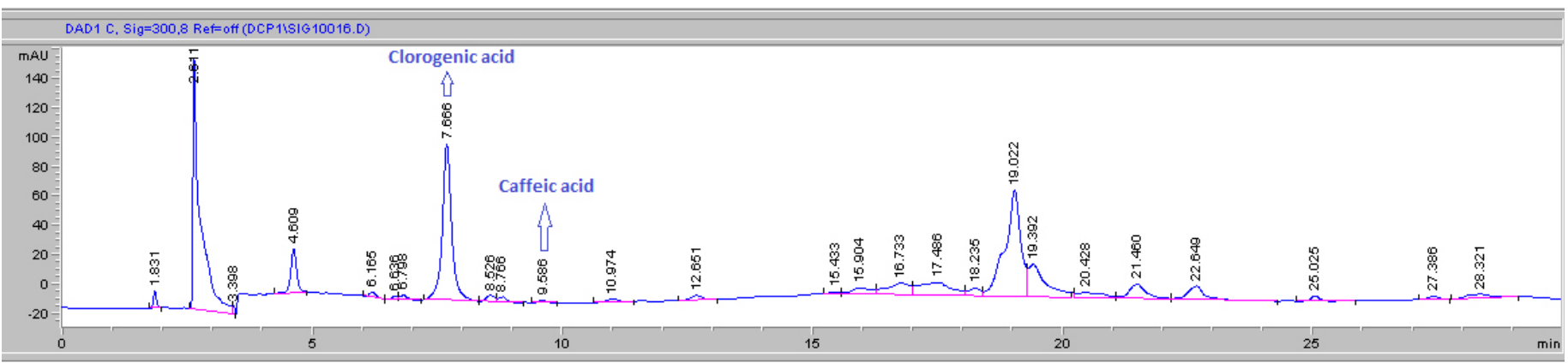

Figure 3. HPLC chromatograms of leaf extract of L. etrusca var. etrusca HPLC: High performance liquid chromatography

Table 2. Calibration values for chlorogenic acid and caffeic acid

\begin{tabular}{lllllll} 
Standard & $\begin{array}{l}\text { Calibration range } \\
(\mu \mathbf{g} / \mathbf{m L})\end{array}$ & $\begin{array}{l}\text { Slope } \\
\left(\mathrm{a} \pm \mathrm{SD}^{*}\right)\end{array}$ & $\begin{array}{l}\text { Intersection } \\
\left(\mathrm{b} \pm \mathrm{SD}^{*}\right)\end{array}$ & $\begin{array}{l}\text { Correlation number } \\
\left(\mathrm{r}^{2} \pm \mathrm{SD}^{*}\right)\end{array}$ & $\mathbf{L O D}(\mu \mathrm{g} / \mathbf{m L})$ & $\mathbf{L O Q}(\mu \mathrm{g} / \mathbf{m L})$ \\
\hline Chlorogenic acid & $5-100$ & $18.733 \pm 1.547$ & $6.692 \pm 1.489$ & $0.995 \pm 0.003$ & 0.093 & 0.311 \\
\hline Caffeic acid & $5-100$ & $81.837 \pm 2.893$ & $20.081 \pm 4.751$ & $0.996 \pm 0.002$ & 0.068 & 0.229 \\
\hline
\end{tabular}

*SD: Standard deviation, LOD: Limit of detection, LOQ: Limit of quantification 
Table 3. Intra-day and inter-day precision's data of the method

\begin{tabular}{|c|c|c|c|}
\hline Standards & Amount $(\mu \mathrm{g} / \mathrm{mL})$ & Intra-day precision (RSD* \%) & Inter-day precision (RSD* \%) \\
\hline \multirow{4}{*}{ Chlorogenic acid } & 10 & 1.364 & 1.774 \\
\hline & 25 & 0.516 & 0.256 \\
\hline & 50 & 0.894 & 0.497 \\
\hline & 100 & 0.713 & 0.461 \\
\hline \multirow{3}{*}{ Caffeic acid } & 5 & 1.649 & 0.892 \\
\hline & 50 & 0.957 & 1.849 \\
\hline & 100 & 1.370 & 0.994 \\
\hline
\end{tabular}

${ }^{*}$ RSD: Relative standard deviation

Table 4. Recovery assay's statistical data of the method (n: 3)

\begin{tabular}{|c|c|c|c|c|c|}
\hline Standards & $\begin{array}{l}\text { Concentration in sample } \\
(\mu \mathrm{g} / \mathrm{mL})\end{array}$ & $\begin{array}{l}\text { Amount spiked } \\
(\mu \mathrm{g} / \mathrm{mL})\end{array}$ & $\begin{array}{l}\text { Mean amount found in } \\
\text { mixture }(\mu \mathrm{g} / \mathrm{mL})\end{array}$ & Mean recovery $\left(\% \pm S D^{*}\right)$ & $\mathrm{RSD} * *$ \\
\hline \multirow[b]{2}{*}{ Chlorogenic acid } & \multirow{2}{*}{0.04} & 0.02 & 0.03 & $99.795 \pm 1.516$ & 1.519 \\
\hline & & 0.04 & 0.04 & $97.638 \pm 1.563$ & 1.601 \\
\hline \multirow{2}{*}{ Caffeic acid } & \multirow{2}{*}{0.006} & 0.003 & 0.0045 & $97.260 \pm 0.507$ & 0.521 \\
\hline & & 0.006 & 0.006 & $102.092 \pm 1.325$ & 1.297 \\
\hline
\end{tabular}

*SD: Standard deviation, ${ }^{*}$ RSD: Relative standard deviation

rectangular cells and is covered by a very thick cuticle. The stomata are rarely observed. The abaxial side of the epidermal layer consists of 8-10 rows of collenchymatous cortex cells and is bordered by the endodermis. The pericycle is in a ring form, consists of fibre-like cells with thick walls and wide lumina. Corks occur to adjoining pericyclic fibers. Phloem is composed of thin-walled cells containing starch grains, sometimes containing sclerenchymatous cells. The pith is heterogeneous. The pith cells with thickened walls surround the xylem and are elongated within the xylem as arms. The arm cells contained very dense starch grains. Thin-walled pith cells contain dense and druse crystals. Dead cells occurred toward the middle of the stem (Figure 4).

\section{Leaf anatomy}

The transverse section of the leaf is broadly $V$-shaped. In the midrib, the upper epidermis consists of single-layered epidermal cells with thickened walls. One-five rows of collenchyma are located under the epidermal layer. Between the main vein and the collenchyma tissue, it is filled is filled with parenchymatous cells. The main vein consists of arc-shaped xylem and phloem. The abaxial side of the phloem is lined with 1-2 layers of bundle sheath-like parenchymatous cells containing dense starch grains in a crescent shape. The walls of the midrib lower epidermal cells are very thick, the lumina of the cells is very narrow compared to the upper epidermal cells. The adaxial side of the lower epidermis is powered with 1-9 rows of collenchyma tissue. The abaxial side of the midrib is more protruding than the adaxial side. The cuticle layer is thinner in the lower
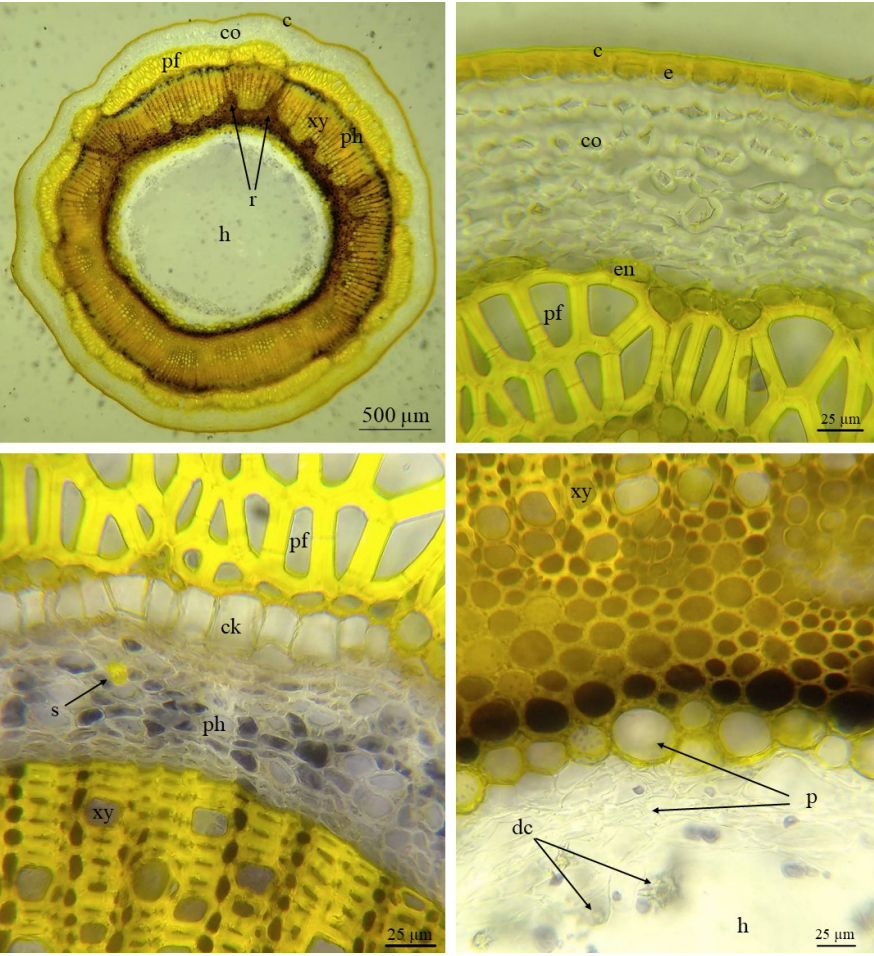

Figure 4. Transverse section of the stem

c: Cuticle, ck: Cork, co: Collenchyma, dc: Druse crystal, e: Epidermis, en: Endodermis, h: Hollow, p: Pith cell, pf: Pericyclic fiber, ph: Phloem, r: Ray, s: Sclerenchymatous cell, $x y$ : Xylem 
epidermis compared with the upper epidermis. The stomata are not observed in the midrib, but contain solitary crystals. The leaf lamina is bifacial in the transverse section. The upper epidermis cells are square with a thick adaxial wall and covered by a thick cuticle layer. A palisade parenchyma consists of a single layer of elongated cells. The spongy parenchyma contains thin walled, 1-8 rows of isodiametric cells. Palisade and spongy parenchyma, both contain abundant starch grains. The lower epidermis cells are rectangular, outer walls are thick and smaller than the upper epidermal cells. The cuticle layer is thinner and stomata are observed. Solitary druse crystals are sparse in the leaf mesophyll (Figure 5).

In the leaf lamina surface sections; the stomata were observed only on the lower surface with 3-5 subsidiary cells. The lower epidermal cells are sinuous. The upper epidermis layer is free of stomata and consists of polygonal epidermal cells (Figure 6).

\section{DISCUSSION}

In this study, leaves and stem of L. etrusca var. etrusca were evaluated in terms of its anatomical structures and phenolic compounds.

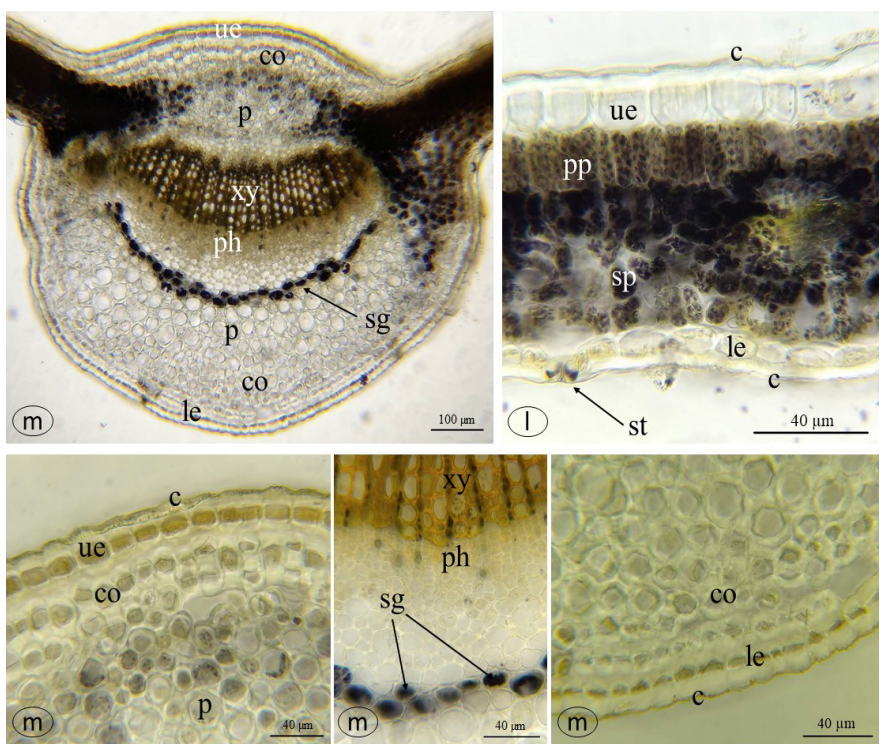

Figure 5. Transverse section of the leaf

c: Cuticle, co: Collenchyma, I: Lamina, le: Lower epidermis, m: Midrib, p: Parenchyma, pp: Palisade parenchyma, ph: Phloem, sg: Starch grains, sp: Spongy parenchyma, st: Stomata, ue: Upper epidermis, xy: Xylem
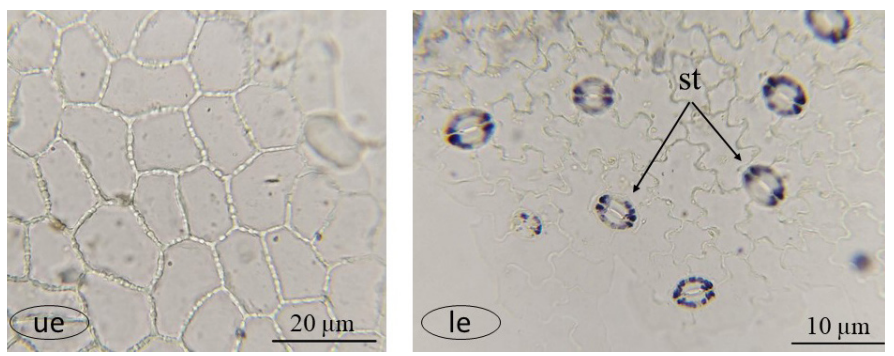

Figure 6. Surface section of the leaf

le: Lower epidermis, st: Stomata, ue: Upper epidermis
HPLC was used for the quantitation of two phenolic compounds, i.e. chlorogenic and caffeic acids, and analysis method used was validated. Chlorogenic and caffeic acids have important biological activities such as antioxidant and anti-inflammatory activities. ${ }^{18,22}$ Since some Lonicera species are used for medicinal purposes, L. etrusca var. etrusca has also been evaluated in terms of its phenolic compounds with biological activity. The results of HPLC analysis, while amount of chlorogenic acid in the stem and leaf was $1.043 \%$ and $1.148 \%$, respectively; the amount of caffeic acid was $0.156 \%$ and $0.073 \%$, respectively. It has been determined that chlorogenic and caffeic acids are among the major phenolic compounds in the stem and leaves of L. etrusca var. etrusca. Phenolic compounds were also detected in some studies with other species ( $L$. japonica, $L$. confusa, $L$. fulvotomentosa, L. macranthoides, and L. hypoglauca). In these studies, it was determined that the amounts of chlorogenic and caffeic acids were similar and chlorogenic acid was higher than caffeic acid. 14,15 These results are consistent with the results of our study.

The results of the anatomical study showed that the transverse section of the stem is hollow, disc-like, and broadly grooved. Epidermal tissue consisting of a single layer of cells is covered with a thick cuticle and rarely stomata are observed. The cortex of stem is characterized by collenchymatous cells and bordered by endodermis. The pericyclic layer is ring-shaped and consists of sclerenchymatous cells with wide lumina and thick-walled. The cork is adjacent to the pericycle layer. Vascular tissue is embedded in the sclerenchymatous pith cells. Phloem sometimes contains sclerenchymatous cells. The pith cells branch out between vascular tissue and starch grains are dense in the pith cells. Thin-walled cells of heterogeneous pith contain dense solitary druse crystals. The anatomical features of stem for Lonicera genera were reported by Metcalfe and Chalk $^{23}$ as cork usually arises in the pericyclic region with wide luminal and thick-walled cells, the pericycle contains wide fibers or fibre-like elements with thin walls and very wide lumina, phloem includes thick-walled fibers and xylem is in the form of a continuous cylinder, cluster crystals present. These reports are similar to the findings of our study. L. etrusca var. etrusca leaf is characterized by bifacial lamina, singlelayered epidermis, palisade parenchyma with elongated, 1-row cells, spongy parenchyma with 1-8 rows of isodiametric cells, abundant starch grains, and sparse solitary druse crystals. The lower surface includes stomata with 3-5 subsidiary and epidermal cells are sinuous. The upper epidermis layer is free of stomata and consists of polygonal epidermal cells. Leaf features of the Caprifoliaceae family are stated by Metcalfe and $\mathrm{Chalk}^{23}$, so dorsiventral leaf, a single layer of palisade, and solitary crystals are the same anatomical features determined as a results of our study. This report indicated that the family has Ranunculaceous stomata, whereas our study showed that L. etrusca var. etrusca has anomocytic stomata.

\section{CONCLUSION}

In this study, stem and leaf anatomy of L. etrusca var. etrusca was studied and the important characteristics were identified. 
The transverse section of the stem looked disc-shaped and hollow. The pericycle consists of fibre-like cells with thick walls and wide lumina and the cork occurs adjoining pericyclic fibers. The leaf anatomical structure is bifacial, the stomata located characterized by on the lower surface with 3-5 subsidiary cells. The mesophyll contains solitary druse crystals. Additionally, the amount of chlorogenic acid and caffeic acid, which are the major compounds, were determined by HPLC. Our results follow studies on other Lonicera species. Method validation was performed to determine the reliability of the method. The anatomy study coincides with the anatomical features of the genus Lonicera. It is important to evaluate these species in terms of anatomical structures and chemical contents, since it is widely grown in our country and is a variety. This study may help minimize confusion between L. etrusca var. etrusca and other Lonicera species, and may support in taxonomically classification for L. etrusca var. etrusca.

\section{Ethics}

Ethics Committee Approval: Not necessary.

Informed Consent: Not necessary.

Peer-review: Externally peer-reviewed.

\section{Authorship Contributions}

Concept: D.C..P., M.M.H., Design: D.Ç.P., M.M.H., Data Collection or Processing: D.C..P., M.M.H., Analysis or Interpretation: D.C..P., M.M.H., Literature Search: D.Ç.P., M.M.H., Writing: M.M.H.

Conflict of Interest: No conflict of interest was declared by the authors.

Financial Disclosure: The authors declared that this study received no financial support.

\section{REFERENCES}

1. Chamberlain DF, Matthews VA. Davis PH (eds). Flora of Turkey and the East Aegean Islands, volume 4. Edinburgh University Press. Series: Flora of Turkey, 1972.

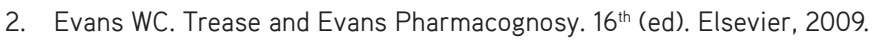

3. Davis PH. Flora of Turkey and the East Aegean Islands (vol 4). Chamberlain DF, MAtthews VA (eds). Edinburgh: Edinburgh University Press. 1972:544-550.

4. Shang X, Pan H, Li M, Miao X, Ding H. Lonicera japonica Thunb.: ethnopharmacology, phytochemistry and pharmacology of an important traditional Chinese medicine. J Ethnopharmacol. 2011;138:1-21.

5. Wang D, Zhao X, Liu Y. Hypoglycemic and hypolipidemic effects of a polysaccharide from flower buds of Lonicera japonica in streptozotocininduced diabetic rats. Int J Biol Macromol. 2017;102:396-404.

6. Liu M, Yu Q, Yi Y, Xiao H, Putra DF, Ke K, Zhang Q, Li P. Antiviral activities of Lonicera japonica Thunb. components against grouper iridovirus in vitro and in vivo. Aquaculture. 2020;519:734882.
7. Peng LY, Mei SX, Jiang B, Zhou H, Sun HD. Constituents from Lonicera japonica. Fitoterapia. 2000;71:713-715.

8. Svarcova I, Heinrich J, Valentova K. Berry fruits as a source of biologically active compounds: the case of Lonicera caerulea. Biomed Pap Med Fac Univ Palacky Olomouc Czech Repub. 2007;151:163-174.

9. Kumar K, Sharma YP, Manhas RK, Bhatia H. Ethnomedicinal plants of Shankaracharya Hill, Srinagar, J\&K, India. J Ethnopharmacol. 2015;170:255-274.

10. Güler $B$, Manav E, Uğurlu E. Medicinal plants used by traditional healers in Bozüyük (Bilecik-Turkey). J Ethnopharmacol. 2015;173:39-47.

11. Baytop T. Türkiye'de Bitkiler ile Tedavi (Geçmiște ve Bugün). Nobel Tıp Kitapevleri, İstanbul; 1999.

12. Guvenalp Z, Ozbek H, Kuruuzum-Uz A, Kazaz C, Demirezer LO. Chemical constituents of Lonicera etrusca. Chem Nat Compd. 2012;48:693-695.

13. Fang Z, Li J, Yang R, Fang L, Zhang Y. A review: the triterpenoid saponins and biological activities of Lonicera Linn. Molecules. 2020;25:3773.

14. Li Y, Kong D, Wu H. Comprehensive chemical analysis of the flower buds of five Lonicera species by ATR-FTIR, HPLC-DAD, and chemometric methods. Rev Bras Farmacogn. 2018;28:533-541.

15. Zhao Y, Dou D, Guo Y, Qi Y, Li J, Jia D. Comparison of the trace elements and active components of Lonicera japonica flos and Lonicera flos using ICP-MS and HPLC-PDA. Biol Trace Elem Res. 2018;183:379-388.

16. Jurikova T, Rop O, Mlcek J, Sochor J, Balla S, Szekeres L, Hegedusova A, Hubalek J, Adam V, Kizek R. Phenolic profile of edible honeysuckle berries (genus Lonicera) and their biological effects. Molecules. 2011;17:61-79.

17. Tanase C, Coşarcă S, Muntean DL. A critical review of phenolic compounds extracted from the bark of woody vascular plants and their potential biological activity. Molecules. 2019;24:1182.

18. Naveed M, Hejazi V, Abbas M, Kamboh AA, Khan GJ, Shumzaid M, Ahmad F, Babazadeh D, FangFang X, Modarresi-Ghazani F, WenHua L, XiaoHui Z. Chlorogenic acid (CGA): a pharmacological review and call for further research. Biomed Pharmacother. 2018;97:67-74.

19. Bahadır Acıkara Ö, Ilhan M, Kurtul E, Šmejkal K, Küpeli Akkol E. Inhibitory activity of Podospermum canum and its active components on collagenase, elastase and hyaluronidase enzymes. Bioorg Chem. 2019;93:103330.

20. Mendes NS, Pereira SM, Arantes MB, Glória LL, Nunes CR, Passos MDS, Vieira IJC, de Moraes LP, Rodrigues R, Oliveira DB. Bioanalytical method validation for the quantification of the chlorogenic acid in Capsicum baccatum through high performance liquid chromatography (HPLCDAD). Food Chem. 2020;325:126929.

21. Çelebioğlu S, Baytop T. A new reagent for microscopial investigation of plant. İstanbul, Publication of the Institute of Pharmacognosy; 1949.

22. Magnani C, Isaac VLB, Correa MA, Salgado HRN. Caffeic acid: a review of its potential use in medications and cosmetics. Anal Methods. 2014;6:3203-3210.

23. Metcalfe CR, Chalk L. Anatomy of the dicotyledons. Oxford: Clarendon Press. 1950:243-245. 